\title{
Translation as destruction: Kezilahabi's adaptation of Heidegger's "Being”
}

\author{
Alena Rettová \\ SOAS University of London \\ ar42@soas.ac.uk
}

\begin{abstract}
Tanzanian novelist and philosopher Euphrase Kezilahabi strives to "dismantle the resemblance of language to the world" (1985: 216) through challenging the fundamental philosophical dichotomy of subject and object. The result of this dismantling will be a new "language whose foundation is Being" (Kezilahabi 1991: 69; lugha ambayo msingi wake ni kuwako). This is an expression of a new relationship between humanity and Being built on a holistic epistemology of experience and embodiment. Through "kuwako", Kezilahabi expresses in Swahili the Heideggerian concept of Sein (Being). His adherence to Heidegger, however, puts him at risk of compromising the very foundation of his own philosophy: his continued critique of essentialism. This article argues that Kezilahabi salvages his concept of "kuwako" from these essentialist pitfalls precisely through his declared "destructive rather than deconstructive stand vis-àvis the Western philosophy of value and representation" (Kezilahabi 1985: 4). The destruction is implemented on the thematic level: a phase of "vurumai" (chaos) which destroys previous traditions of philosophy is staged in Nagona. However, translation is an even more powerful device to carry out this destruction: "kuwako" is not an innocent reiteration but a radical reformulation of Heidegger's central philosophical concept, decisively informed by Kezilahabi's lifelong propensity for existentialism.
\end{abstract} Keywords: Euphrase Kezilahabi, Martin Heidegger, Hermeneutics of translation, Swahili literature, African epistemology

\section{Introduction: Nagona and Mzingile}

"Texts that impede Swahili literature." Such was the verdict of prominent literary critic Mwenda Mbatiah (see Tchokothe 2014: 141) about the two novels produced by the famous Tanzanian writer, Euphrase Kezilahabi, in the early 1990s. Lacking an elaborate plot, the two narratives follow a meandering male protagonist through unknown, hostile landscapes, collapsing time and questioning such basic ontological concepts as unity, identity, or causality. Kezilahabi's dramatic literary turn, introducing these radical stylistic and thematic innovations, launched what has come to be known as the "new Swahili novel" (Gromov 2014: 40). After Nagona (proper name, 1990) and Mzingile (Labyrinth, 1991), several authors followed suit and published similarly enigmatic, although rarely comparably philosophically profound, novels: "fiction that challenges the customary ontological boundaries of a hitherto 'broadly' realist mainstream 
tradition" (Khamis 2005: 92). The "new Swahili novel" broadly converges with postmodernist writing in the West, but it maintains distinct features of postcolonial literature, both in its style and in its political commitment (Rettová 2016a; 2016b): Swahili writers draw on "indigenous" ontologies (introducing spirits, zombies, using metamorphoses between animals and humans, etc.); they employ narrative techniques derived from the oral tradition (using circular plots, specific topoi, settings, styles of characterization, etc.); and they critique manifestations of the political and intellectual hegemony of the West.

But Nagona and Mzingile are not only literary innovations. They are in fact a literary implementation of Kezilahabi's philosophy, elaborated five years earlier in his doctoral thesis "African philosophy and the problem of literary interpretation" (1985). In the Swahili novels, Kezilahabi puts into literary practice the ideas projected in the thesis, but arguably he goes one step further in being more radical in his criticism of Western philosophy.

In several passages in these two novels, Kezilahabi translates Western philosophical concepts into Swahili. For instance, in discussions with a scientist who tries to change the order of nature, the main protagonist (who is also the first-person narrator of most of the chapters) summarizes:

Baada ya hapo tulikuwa na majadiliano makali kuhusu umuhimu wa vurumai katika fikra, na ulazima wa kuvunja uhusiano uliopo kati ya Mtu na Kitu (Kezilahabi 1991: 52).

After that we had incisive discussions concerning the importance of chaos in thought and the need to break the relationship that exists between Man and Thing. ${ }^{1}$

The capitalized words Mtu ("Man") and Kitu ("Thing”) are Kezilahabi's Swahili renditions of "subject" and "object". This becomes clear from similar passages in his doctoral thesis, where he writes:

[A]n ontological approach [to literature] goes beyond categories of Subject/Object. (...) The African onto-critic (...) has to avoid the tragic epistemology of Western man (Kezilahabi 1985: 215-9).

The same concepts are evoked again in a passage at the end of Mzingile where the main protagonist discusses the arrangement of a future, post-apocalyptic world with a mysterious woman with a shining body:

"Sasa nafikiri yafaa tuanzishe lugha mpya", nilitoa wazo.

"Nami pia nimekuwa nikifikiria wazo hilo. Tutahitaji lugha ambayo haina cha Mtu na Kitu."

"Yafaa pia lugha hiyo isiwe na maneno kama 'nyuklia' au 'vita'. Tutaunda lugha ambayo msingi wake ni kuwako.” (Kezilahabi 1991: 69.)

1 All translations in this article are mine, unless indicated otherwise. 
"Now, I think we should create a new language", I voiced a thought.

"I have been thinking of that, too. We will need a language that does not contain the issue of Man and Thing."

"This language should also not contain words like 'nuclear' and 'war'. We shall create a language whose foundation is being."

Another concept appears here, kuwako ("being"), which is Kezilahabi's translation of the Heideggerian "Being", a concept which, again, appears many times in Kezilahabi's thesis:

... Language is more than a signifying system. Language is the "house of Being". By writing in foreign languages we allow the Western world to be the center of value of our Being (Kezilahabi 1985: 359).

The Heideggerian provenance of this concept in Kezilahabi's thesis is undeniable. In this passage, he capitalizes "Being", following the usus of translating the concept into English, and the passage also contains an (unacknowledged) direct quotation of Heidegger: "Language is the house of being" (Heidegger 1998: 239).

Through these words Kezilahabi expresses in Swahili central concepts of Western philosophy: the concepts of subject and object and, in particular, the Heideggerian concept of Sein (Being). Together with Marx and Nietzsche, Heidegger is one of the three Western philosophers who have informed the philosophical project Kezilahabi develops in his doctoral dissertation, and "Being" becomes one of his key concepts.

\section{Kezilahabi's philosophical project}

In his thesis Kezilahabi says the African literary critic "has to take a destructive rather than a deconstructive stand vis-à-vis the Western philosophy of value and representation" (Kezilahabi 1985: 4). This will help it to prevent African experience from being "objectified and reduced to a body of knowledge that signifies" (Kezilahabi 1985: 194) in that the critic captures "the ontological aspect of metaphor, symbol and ritual" (1985: 215).

For Kezilahabi, the "tragic epistemology of Western man" (1985: 219), consisting in the deadly split of the totality of being into "the categories of Subject/Object" (Kezilahabi 1985:215), is manifested in the view of literature as representation, and Kezilahabi strives to challenge this view of literature through "dismantl[ing] the resemblance of language to the world" (1985: 216). His two experimental novels in Swahili, Nagona and Mzingile, are a result of this theoretical argument. The dismantling of the resemblance of language to the world is done in the two novels both on the level of style: through the employment of a non-linear, meandering plot; through lack of temporal and spatial coherence, a radical disruption of habitual ontology, etc.; and on the level of discourse: in several places, especially in the final scenes of Mzingile, the protagonists discuss the creation of a new "language" as a way to heal the deadly fractures of epistemology: they plan to "create a language whose foundation is being" (Kezilahabi 1991: 69). This is a projection of a new relationship between humanity and being on the foundation of a holistic epistemology.

The radical rejection of the distinction between subject and object is at the basis of Kezilahabi's project of writing. He dubs this project "onto-criticism" 
as an approach to African literature which is superior to "techno-criticism": the criticism of African literature as done by foreign critics incapable of deep hermeneutical insights into African being. Through "onto-criticism" Kezilahabi aspires to destroy the semblance of language and the world, which he sees as just another instance of the subject-object relationship, and the idea of seeing literature as a body that represents, that reflects the world:

The onto-critic is engaged in the liberation of words from conventions, and seeks to displace and decenter logocentrism and signification by making relations empty of meaning and by dismantling the resemblance of language to the world. ... To an onto-critic ... literature is not a reorganization of impulses but an ontological understanding that is projective. (Kezilahabi 1985: 217-8.)

He is seeking an alternative model of literature challenging the theory of literature as mimesis.

The abolition of the split between subject and object can be understood in several ways, in addition to the ontological reading of literature. Lanfranchi suggests the idea of intuition: "a notion of reason that is intuitive and emphatic" (2015: 177). This comes close to Husserl's insistence on the role of intuition in knowledge. However, for Husserl, intuition is firmly rooted within the confines of the subject-object dichotomy. Senegalese poet, philosopher, and politician Léopold Sédar Senghor offers another reading of the non-separation of subject and object as embodiment, similarly to mimesis in art. Mimesis is still a reproduction of the world, but it is a holistic experience from the perspective of the knowing subject. Senghor's "dancing the other" (Senghor 1995) suggests a theory of art and literature as embodied and lived. Yet it is not projective but reproductive: it mirrors lived life. A philosophy of embodiment is therefore not sufficient for Kezilahabi as it does not account for the projective element in literature for its creative freedom.

The abandonment of the subject-object dichotomy implies knowledge which does not go via the conscious mind as cogito and via textual (linguistic) representation. Kezilahabi speaks of "sensibility, attunement, immersion and meditation without an intermediary or articulated discourse” (1985: 219). For a literary project, there is an obvious contradiction: how can literature transcend "articulated discourse", beyond the most banal (cf. Kezilahabi's poem "Pa!", Kezilahabi 2008: 60; see also Gaudioso 2014: 93)? If Kezilahabi challenges the referentiality of language in literature, what is then literature beyond referentiality? The new language in fact abolishes the whole structure of signification. Instead of replicating reality through representation, the writer should instead "let truth be by privileging the silent language of Being" (Kezilahabi 1985: 2). What does this mean? What role does "Being" have in Kezilahabi's philosophy? How is "Being" related to the project of writing in freedom and being creative through writing?

"Being" is a concept of Heideggerian origin: "In Heidegger's thought, 'man' is the privileged channel of expression of 'being' (Sein) in his existential constitution as Dasein (there-Being) and in his use of art and language - especially poetic language - through which being is disclosed" (Lanfranchi 2015: $178 \mathrm{f}$.). 
Heidegger's romanticist philosophy advocating the abandonment of reason becomes integral to Kezilahabi's project. But here Kezilahabi has entered a dangerous terrain. His reliance on Heidegger leads to problematic links to essentialism which are contradictory to Kezilahabi's own criticism of essentialism. Kezilahabi profiles himself as a strong critic of essentialism throughout his doctoral thesis:

Africa has been plagued with philosophies of origin. In the Western world this very philosophy culminated in Nazi Germany, and we know the consequences of this philosophy. The oldest is not necessarily the nearest to our true Being, neither does it have a mandate to rule the present. It does not greatly matter whether we are the real true heirs to the "Stolen legacy". What matters is what we are. A philosophy of origins is a Fascist enterprise. Philosophies of origins are another error. (Kezilahabi 1985: 357-8, emphasis added.)

This article identifies the tensions between Heidegger's philosophy and Kezilahabi's incisive critique of the "philosophies of origin" as essentialist philosophies and ideologies that have been adopted by Africans to the detriment of the continent's prosperity and development. The reliance on Heidegger effectively puts Kezilahabi at risk of compromising the very foundations of his philosophical project.

However, the article also argues that Kezilahabi salvages his concept of kuwako (being) from these essentialist pitfalls precisely through his declared project of "tak[ing] a destructive rather than a deconstructive stand vis-à-vis the Western philosophy of value and representation" (Kezilahabi 1985: 4). Having passed the phase of vurumai ("chaos"; in the novels, a chaotic philosophical dance that destroys millions of people), kuwako crucially reformulates and redefines Heidegger's central philosophical concept and comes to reflect Kezilahabi's anti-essentialist stance. I further argue that the ultimate destruction is effectuated through the act of translation. In its new linguistic form, kuwako acquires a strongly existentialist meaning.

\section{Kezilahabi and Heidegger}

Heidegger is one of Kezilahabi's "eye-openers" (1985: 5-6): one of three philosophers who "lay bare the nature of the Western world" (1985: 5); the other two are Marx and Nietzsche. ${ }^{2}$ The strong influence of Heidegger on Kezilahabi is

2 Criticizing Kezilahabi's essentialism, visible in the stark "Africa/the West" dichotomy, Gaudioso demonstrates that these thinkers were in no way alone in Western philosophy: "Heidegger and Nietzsche are not isolated figures, but rather ... one part of Western philosophy was used to challenge and reform another part. This makes impossible the dichotomic essentialism professed by Kezilahabi" (Gaudioso forthcoming). Lanfranchi $(2012 ; 2015)$ is also critical of Kezilahabi's simplistic and essentialist view of Western philosophy. Not least because of this simplification, Kezilahabi's ambition to depart from Western philosophy is compromised: in his thesis, he pits two trends of Western philosophy against one another and reinterprets one as being uniquely "African". A 
evident in Kezilahabi's adoption of the concept of "Being"; this shows in many ways in his statements about the relationship between language and Being; in his belief that Being is disclosed through poetic language; or in his concept of "ontology". His thesis teems with both direct and indirect quotations of the German philosopher, and Heidegger is also the basis of Kezilahabi's theorization of literature and literary criticism.

Kezilahabi based his critique of Western literary criticism on an incisive critique of essentialism. It is here that he is perhaps not well served by Heideggerian philosophy. Heidegger himself, despite being an avowed "philosopher of existence" (cf. Löwith 1991), did not resist the seductive power of essentialism. On the political level, he notoriously fell for the ideology of Nazism in the 1930s. However, essentialism also penetrates the philosophical level in Heidegger's thought.

Heidegger's political involvement is well known and well documented (Farías 1989, Wolin 1991, Ott 1993, Safranski 1998, Faye 2009). He was appointed rector of Freiburg University in 1933 and became "a zealous propagandist on behalf of the new regime in its initial stages" (Wolin 1991: 2). He was a member of the National Socialist German Workers' Party (NSDAP) from 1933 until 1945. He sympathized with extreme-right attitudes, but he eventually distanced himself from Hitler because he felt contempt for the vulgarity of the Nazi party. After the Second World War, and following the denazification phase (1946-49), he was readmitted to the university in 1950-51 and was made emeritus.

His sympathy for Nazism was motivated by the belief that "National Socialism possessed the capacity to initiate a great spiritual renewal of German Dasein" (Wolin 1991: 2). It had the potential to reverse the spiritual decline of Europe, first voiced by Friedrich Nietzsche and later theorized by conservative philosophers such as Oswald Spengler, Ludwig Klages, and Ernst Jünger. Heidegger considered his political commitments "as of a piece with his philosophy" (Wolin 1991: 4): his support of National Socialism in 1933 was a "decision for authenticity" (ibid.). The conceptual framework of Heidegger's magnum opus, Being and Time (1927), not only "proved readily compatible" (Wolin 1991: 5) with Nazism, but Nazism, according to Emmanuel Faye, "inspired [Heidegger's] works in their entirety and nourished them at the root level" (Faye 2009: 6-7). Indeed, Heideggerian philosophy shares the same premises as Nazism, and exhibits common salient features. These include nationalism, with its appeal to Grund und Boden ("rootedness of existence", "soil", see Heidegger 1996: §25), and its determinism by birth, seeing Germans as the central pillars of Western culture; irrationalism,

rather different question, however, is how the translation of philosophical concepts into Swahili contributes to their recontextualization and reinterpretation in another cultural context. The resulting philosophy may, in one way or another, concur with trends of Western philosophy (for instance, existentialism); yet, it is distinctly African in the sense of deriving meaning from an African cultural context. At the same time, "distinctly African" should not be read in an essentialist sense: there are many such "African contexts" and many such "distinctly African philosophies". 
emphasizing the deep, hidden reality, and the insufficiency of critical reason in uncovering this reality; and the rejection of individuality and democracy (Kohák 1995).

Nation is not a name for a group of people assembled through historical contingency but for a biological fact: the nation is an organism of which individuals are members. Nationalism is based on the belief in a deep determination of "nation": some nations are creators of culture (Germans), others destroy culture (Jews, Roma, Slavs). There is no possibility of a conscious decision to become a member of a nation: a Jew cannot decide to be German. "Der Jude kann nur jüdisch denken. Schreibt er deutsch, dann lügt er. Der Deutsche, der deutsch schreibt, aber jüdisch denkt, ist ein Verräter", 3 said the anti-Semitic pamphlet of the German Student Union (Deutsche Studentenschaft) published in 1938 by Ernst Forsthoff alongside excerpts from Heidegger's Rectorship Address (Rektoratsrede, titled "The Self-Assertion of the German University"). The publication of the Rektoratsrede on pages mirroring this declaration is telling, as Heidegger's impassioned speech is fully consonant with such nationalist positions. His strongly anti-Semitic opinions were fully revealed in the recent publication of his Black Notebooks from 1931-45, and he also firmly believed in the special genius of the German people. In the Rectorship Address, he speaks of "the inexorability of that spiritual mission which impresses onto the fate of the German Volk the stamp of their history" (Heidegger 1991: 29) and of "the will to the historical spiritual mission of the German Volk as a Volk that knows itself in its state" (1991: 30). This "spiritual mission" means that "for Europe itself [Germany's] historical Dasein proves to be the center", as Heidegger claimed in 1935 (Heidegger 2000: 44). As late as 1943 he writes that "only from the Germans can there come a world-historical reflection - if ... they can find and preserve their 'Germanness' ('das Deutsche')" (quoted in Wolin 1991: 14).

To Hitler, the nation is mystical reality, a connection by blood. Intuition is a higher degree of recognition in comparison with mere rationality. Heidegger's philosophy is also an intuitive, emotive search for the true meaning of phenomena, which is hidden in everydayness. Argument is not the right method of philosophy, it is rather opening up and securing an extra-rational access to truth through "listening to Being": "Da-sein's thinking is a listening to Being's selfdisclosure" (Zeytinoglu 2011: 277). On account of such formulations, Wolin likens Heidegger's philosophical style to "that of a prophet who views himself as standing in a position of immediate access to Being" (1991: 11).

It is on the basis of such experience that Heidegger introduces two concepts "inauthenticity" as escaping our fundamental possibilities and "authenticity" as the opening up of consciousness to the human situation, to life in confrontation with one's own finitude: ("Being-unto-Death"). The mystical access to "Being" makes of truth a gift of disclosedness and unveiling (aletheia). Faye points out that the "radicalism of the pure decision on the part of an existent facing nothingness, which no rational motive can support nor any warning of its destructive

3 "A Jew can only think in a Jewish way. If he writes in German, then he is lying. A German who writes German but thinks Jewish, is a traitor." My translation. 
effects forestall, inhabits the very foundation of Nazism" (2009: 9). "The pure decision in preparation for an 'authentic' existence, authorized only by itself, [which] tends to deny all deliberation, all prudence, and eventually all real thought" (ibid.), is equally at the very core of Heidegger's philosophy in Being and Time.

The rejection of democracy derives from the fact that democracy is based on individualism, which, for Heidegger, is symptomatic of "a nihilistic Western modernity" where "the self-enclosed, monadic individual has emerged as [the] absolute point of reference [of politics]" (Wolin 1991: 7). This vulgar and subjectivist "antithesis to the classical polis, in which the individual good was always subordinated to the good of the whole" is to be overcome by "a new heroic ethos" (ibid.). In this ideology the German nation has the historical role of gaining power over the world (Griff nach der Weltmacht). War is the fulfilment of its historical vocation. It was from the "community of destiny" (Schicksalsgemeinschaft) and the "community of the people" (Volksgemeinschaft) (see Faye 2009: 16) that Heidegger envisaged refuting "the philosophy of human individuality and the Cartesian self' (Faye 2009: 9). As Faye argues, Heidegger's linguistic strategy, when he dropped the reference to the human subject in favour of the term "Dasein", enabled him a surreptitious substitution of a philosophy of human individuality with that founded on a collective entity, the Volk (Heidegger 1996: §§ 27 and 74).

\section{Liaisons dangereuses}

Kezilahabi interiorizes the essentialist foundations of Heidegger's philosophy. He upholds an essentialist concept of "African being": "inauthenticity is ... identified with Western fragmentative thinking, while authenticity is defined in terms of the African worldview as inherently disclosing of true being" (Lanfranchi 2015: 179) and entertains "an essentialist notion of African authenticity" (Lanfranchi 2015: 180), in identifying "the African experience [with] an ontological form of consciousness tied to Being" (Kezilahabi 1985: 194).

Indeed, Kezilahabi draws a sharp distinction between the "techno-critic" and "onto-critic". While the former only acquires "knowledge" through objectifying processes, the latter has an intimate access to truth and Being through "understanding": " "understanding' has an area of overtones which 'knowing' can never reach" (Kezilahabi 1985: 219). ${ }^{4}$ He categorically states:

A distinction can be made between the "language" of theory and the language of thinking. The "language" of theory is grounded in techne, the language of thinking in Being. The "language" of theory and knowing demands accurate observation and accurate tools. The language of thinking and understanding demands sensibility, attunement, immersion and meditation without an intermediary or articulated discourse (Kezilahabi 1985: 219).

4 Kezilahabi reiterated his views during his lecture entitled "The real and the imaginary: propellers of knowledge in literature" in the BIGSAS Denkatelier 03 at the University of Bayreuth, on 26 May 2017. 
This passage shows the centrality of Kezilahabi's notion of "language" (lugha, in Swahili), and it also explains his understanding of the abolition of the subject/ object dichotomy, which is clearly formulated along Heideggerian lines: "Understanding cannot be articulated through a theory of knowledge because it is not based on communication. It is based on the language of Being" (1985: 221).

For Kezilahabi, only an African has the capacity to become an onto-critic, provided s/he extricates him/herself from Western theory; a foreigner can never gain that special access to African being and truly understand African literature:

... However much a foreign critic may try to understand the African experience he will never get to the core because there is a difference between knowing and understanding. There is always an infinite horizon beyond articulated speech involved in understanding. That horizon requires pre-knowledge and is deeply rooted in tradition (Kezilahabi 1985: 194-5).

Kezilahabi certainly presents a valid point here, referring to the hermeneutical horizon of understanding (see below). The problem, however, is when he speaks of "the core" and of "African experience". What enables qualifying certain experience as "African"? And what is "the core"? It is here that Kezilahabi's language becomes esoteric: he speaks of "leaps to primordial truth and belonging without an intermediary" (1985: 216) as the way to access this "core", whereby this immediacy is only accessible to the "onto-critic" (i.e. an African), because $\mathrm{s} /$ he "extends the domain of understanding beyond objectification and identifies language with Being" (1985: 217). Understanding is characterized by an immediacy of access to truth, an immediacy which knowledge replaces with the study of ideas and the intermediary of theory and technology:

Briefly we may define understanding as the ability to project oneself upon a possibility by way of the present without an intermediary, and knowing as the ability to be acquainted with ideas, facts and concepts through actual experience or given data (Kezilahabi 1985: 216).

The Heideggerian inspiration for Kezilahabi's formulations is exceedingly clear: "Onto-criticism seeks to rectify the decentralization of Being to the periphery by theory through the reinstitution of ontology" (1985: 220) and it is "only possible if language is treated as 'disclosure,' as an opening, as 'the house of Being", (1985: 222).

Heidegger's "authenticity" (Eigentlichkeit) secures a direct, unmediated access to "Being". It was precisely the concept of "authenticity", however, that was seen as problematic soon after its introduction into philosophy; it restitutes an essentialist concept of humanity. This aspect of Heidegger's philosophy was criticized by Jean-Paul Sartre in Being and Nothingness (1958), where being becomes the emptiness of freedom.

Embracing the irrationalism of the Heideggerian concepts of Being and authenticity, present in the intuition or disclosure of Being as truth (aletheia) 
and the determinism of (linguistic, national, racial...) privilege of that disclosure to specific individuals, Kezilahabi strays into stark essentialism. Can we extricate Kezilahabi from this enmeshment with the essentialism implicit in Martin Heidegger's philosophy and save his philosophical project from internal contradiction? More specifically, can we read Kezilahabi's kuwako beyond the Heideggerian dynamics of authenticity and Being?

I argue in the following that Kezilahabi saves his concept of kuwako from these essentialist pitfalls precisely through "being destructive" to Western philosophy. Part of this destruction is also the translation of philosophical concepts into Swahili. But this only happens in Kezilahabi's fictional writing, for it is here that the translation has taken place. By contrast, Kezilahabi's theoretical writings, mainly his doctoral thesis, were written in English and cannot profit from this extra step. If the thesis can easily be classified as essentialist, despite its proclamations to the contrary, the Swahiliphone novels are both more openended and more intriguing.

\section{Translation as destruction}

African literary criticism has to take a destructive rather than a deconstructive stand vis-à-vis the Western philosophy of value and representation (Kezilahabi 1985: 4, emphasis in bold added).

With clear echoes of Fanon, Kezilahabi boldly proclaims that African literature, and by extension African philosophy as the understanding underpinning African literature, must "do violence to all forms of codification and signification, all forms of Western style and genres" (1985: 110). African philosophy must be "destructive" to Western philosophy. The question that imposes itself here is: is Kezilahabi destructive also to his "eye-openers"?

In the two novels, "violence" is done to Western philosophy in the scene of destruction that is the dance competition at the end of Nagona, called Ngoma Kuu ("Big dance"). Ngoma Kuu is an allegoric portrayal of the history of philosophy. It presents four selected dances: Ngoma hizi zilikuwa ngoma mashuhuri wakati fulani katika mkondo wa historia (these were famous dances at some point in the course of history, 1990: 57). The first is a well-arranged dance of songs such as De Anima, Politica, Metaphysica and De Poetica (1990: 58). The second is a psychologist's dance of songs such as Totem, Oedipus Complex and Neurosis. Kezilahabi's first eye-opener, Karl Marx, makes his entry as the third group:

Ngoma ya tatu iliingia kwa kelele za "Chinja! Chinja!” Ngoma hii ilikuwa ikiongozwa na mtu aliyejiita mwanamapinduzi na mtetezi wa wanyonge. Wafuasi wake waliingia katika duara wakiimba wimbo wa kimapinduzi. Kiongozi wao alikuwa amefuga madevu ya kutisha. "Babu huyu vipi!" nilisikia mmoja kati ya watazamaji akisema. Kiongozi wao alinyoosha usinga wake juu akatongoa nyimbo kuhusu maproletariati. Wafuasi wake waliitikia kwa maneno yaliyohusu ubepari na usoshalisti. Walimalizia na nyimbo zilizohusu mikinzano ya kitabaka na majilio ya usawa. Nilisikia baadhi ya watazamaji wakisema, "Babu huyu anasema maneno ya busara." 
Lakini alipoanza kuonyesha usinga wake kuelekea baadhi ya watu aliowaita wanyonyaji hadharani, wafanyakazi wao walianza kumtupia mawe. Wakati wao wa kuonyesha malimboto ulipowadia waliingia watu wenye njaa wakimkatakata vipande mtu mmoja aliyeitwa bepari. Wakati huu waliimba na kupiga kelele "Wafanyakazi wote ulimwenguni unganeni!" Nyimbo zao zilijaa majuzuu na majuzuu, ilibidi waondolewe kwa nguvu kutoka katikati ya duara maana walizidisha muda. Walikataa kutoka kitovuni wakidai kwamba wakati wao wa kushika nafasi hiyo ulikuwa umewadia. Kila mtu aliyewagusa walimwita mpinga mapinduzi. Walitolewa nje hali wakiimba "A lutta Continua" (Kezilahabi 1990: 58-9).

The third dance came with shouts of "Slaughter! Slaughter!" This dance was led by a man who called himself a revolutionary and a defender of the weak. His followers entered the circle singing a revolutionary song. Their leader had grown a fearsome beard. "Look at that old man!" I heard someone in the audience say. Their leader straightened his flywhisk over his head and then he sang songs about the proletariat. His followers answered with words about capitalism and socialism. Eventually they sang songs about class struggle and the coming of equality. I heard some people in the audience saying, "This old man is speaking words of wisdom". But when he started pointing his flywhisk towards some people whom he publicly called parasites, their workers started hurling stones at him. When their time to show masterpiece tricks came, hungry people entered and cut into pieces a person who was called a capitalist. At this time they sang and shouted "Workers of the world, unite!" Their songs filled volumes and volumes and they had to be removed from the centre of the circle by force, because they exceeded their time. They refused to leave the centre claiming that their time to hold that position had come. Anyone who touched them was called a counter-revolutionary. They were dragged out singing "A luta continua".

Kezilahabi presents a scathing parody of Marxist ideology in this passage. Marx is not only forcibly removed from the circle. He is replaced by the final group, the group of madmen, who start dancing chaotically. Their dance overrides the whole scene, millions of people are trampled to death and many others are wounded.

Kezilahabi's second eye-opener, Nietzsche, does not appear as a dancer in the big dancing competition, but there is a clear allusion to him in the scene of a tightrope walker who, unlike in the Nietzschean reading, fails his acrobatic piece:

Tuliendelea kucheza kwa vurumai. Wakati wa malimboto ulipofika, kiongozi wetu aliingia amepanda juu ya mgongo wa simba na juu angani mwanasarakasi akawa anatembea juu ya uzi. Watu walishikilia roho zao. Alipofika katikati aliteleza akaanguka chini. Alikufa palepale, lakini hakuna aliyemjali. Tuliendelea kucheza kwa vurumai na baadhi ya wachezaji wetu walimkanyagakanyaga akasagika. Tulipiga kelele "Vurumai!" (Kezilahabi 1990: 59). 
We continued dancing in chaos. When the time to show masterpiece tricks came, our leader entered on top of a lion and up in the sky a circus performer started walking on a tightrope. People held their breath. When he arrived in the middle, he slipped and fell down. He died on the spot, but there was no one who bothered about him. We continued dancing in chaos and some of our dancers stamped on him until he was crushed to powder. We shouted: "Chaos!".

Nietzsche, famously, presents the tightrope walker and lets Zarathustra philosophize on the basis of this tableau:

Der Mensch ist ein Seil, geknüpft zwischen Thier und Übermensch, ein Seil über einem Abgrunde. (Nietzsche, no date).

Man is a rope stretched between the animal and the Superman - a rope over an abyss (Nietzsche 2008).

The rope, to Nietzsche, is humanity. That the tightrope walker fails to cross it, and worse still, nobody even cares that he has been crushed to powder, equals an annihilation of Nietzschean philosophy.

The chaotic dance leads to a mass destruction of humanity, humanity's history and philosophy. This is instrumental to a radical reconfiguration of being and knowledge after the destruction. The concluding passages of Mzingile present an idyllic, paradise-like existence of a man (the protagonist) and a woman, who live together in a state of innocence, playing like children all day. Animals smile and eat grass, the lion grazing next to the zebra. All books have been burnt, even the knowledge of fire has been forgotten, and the new humanity invents a language that "does not distinguish between Man and Thing", as we have seen above, and that is based on pure existence. What has become of the Heideggerian "Being" after vurumai, "chaos", the act of destruction? And what has become of "Being" through the act of translation into Swahili? We must look at translation here.

\section{Translation and hermeneutics}

Translation is for Kezilahabi not a neutral act. This derives from his understanding of hermeneutics and its foundation in language. Kezilahabi introduces the term "horizon of the unsaid" (1985: 224) to refer to the Gadamerian "horizon of understanding". He explains: "The horizon of the unsaid is a circle of understanding which cannot simply be entered into by means of arbitrary chosen theories of knowledge" (Kezilahabi 1985: 226). Kezilahabi links the "horizon of the unsaid" to a theory of linguistic relativity: African languages are carriers of African culture. Foreign languages "objectify [Africans'] views within [their] signifying systems" and "push [them] to orchestrate peculiarities of [their] own cultures". As a result of this, African literature becomes "a literature of odes to the exotica and vulgar anthropologism" and "a "phenomenology of prostitution"' (Kezilahabi 1985: 359). This harsh criticism of conceptualizations of African experience within foreign signifying systems, as in Europhone 
African literature, explains Kezilahabi's effort to talk about Western philosophy in African languages and to recontextualize the problems of Western philosophy, which undeniably and inevitably affect Africa, within Afrophone intellectual traditions. Challenging the "colonization of the mind" (Ngugi 1981) implicit in the employment of European languages to express African realities, Kezilahabi uses African words, with the semantics and the hermeneutical horizons of these languages, to speak about philosophical concepts, including concepts originating in the European tradition of philosophy. In this, Kezilahabi is far more radical than Ngugi. The "suggestive power [of language] well beyond the immediate and lexical meaning" (1981: 11), which differentiates the African mother tongue from the adopted colonial language in Ngugi's view, refers to the level of connotative meanings of language. While Kezilahabi subsumes connotative meanings under his concept of the "horizon of the unsaid", he additionally demonstrates that words that are apparent translations also have different denotative meanings.

Kezilahabi translates "subject" and "object" as Mtu and Kitu. ${ }^{5}$ This translation rests on the structure of Bantu languages: the words belong to noun classes existing in these languages and are related to other words in different classes. Class $1 m(u)$ - mostly refers to people (e.g. $m t u$, "person, human being"), class $7 \mathrm{ki}$ - mostly refers to things (kitu, "thing"), class $11 / 14 u$ - is the class of abstract nouns (utu, "humanity"), etc. The structure of Bantu languages was famously theorized as "Bantu philosophy" by Alexis Kagame. In his La philosophie bantu-rwandaise de l'Etre (1955), he identified four ontological categories (compared to Aristotle's ten): umuntu, abantu - intelligent being (Aristotle's substance); ikintu, ibintu - a being without intelligence, animals, plants (substance); ahantu - determination of time and space; ukuntu - modality (quantity, quality, relation, activity, passivity, position, possession). In La philosophie Bantu comparée (1976), Kagame expanded his view to include many Bantu languages and cultures to prove his point about a common philosophical understanding of the world among the Bantu, ${ }^{6}$ involving the four categories.

The reaction of Abdilatif Abdalla, a Kenyan poet and language expert as well as a native speaker of Swahili firmly rooted in Swahili culture, to Kezilahabi's text is illustrative of the recontextualization of Western philosophy within a Swahili, or even Bantu, conceptual framework. When asked about the meaning of the passage in Kezilahabi's novels, he immediately said the words Mtu and Kitu were alluding to the Swahili proverb "mtu si kitu", "a person is not a thing", i.e. a person must not be treated like a thing (personal communication, July 2003). The proverb emphasizes the need to treat human beings with due dignity and respect or, to use Kantian terminology, as "ends in themselves" (although neither Abdalla nor Kezilahabi is explicitly referring to Kantian

5 It is very clear that Kezilahabi is speaking of "subject" and "object" in an epistemological sense. The Swahili words for grammatical "subject" and "object" are kiima and shamirisho (see TUKI 1990, Massamba 2004).

6 The Bantu are ethnic groups inhabiting most of the African continent south of the Equator. They speak some 400 closely related languages, including Swahili, Zulu, Xhosa, Shona, etc. All Bantu languages share the basic grammatical structure involving the characteristic system of noun classes, but they also have many common lexical items. 
practical philosophy here). The translated concepts feed into a new "horizon of the unsaid"; they are recontextualized within another culture, in this case within the Swahili philosophy of utu (see Rettová 2007). While Abdalla's understanding diverges from Kezilahabi's use of Mtu and Kitu as translations of "subject/ object", it connects Kezilahabi's writings with an existing Swahili philosophical discourse and conceptual framework, with the important implication of redefining an epistemological problem as a moral one. But there are yet more readings that unfold through this cultural recontextualization. In the earlier passages of Mzingile, humanity's superiority over Nature is questioned in the discussions between the main character and the scientist; the content of these discussions is then summarized as referring to uhusiano uliopo kati ya Mtu na Kitu ("The relationship that exists between Man and Thing", Kezilahabi 1991: 52, see also above). If Mtu and Kitu are also understood as Kagame's categories of being, the erasure of the boundary between Mtu and Kitu can be understood as a negation of the ontological difference between "humans" and "nonhumans" ("things", "Nature"). Nagona and Mzingile would then lend themselves to topical environmentalist (posthumanist, ecocritical) readings (Rettová forthcoming).

\section{What is kuwako?}

It is the translation of the Heideggerian concept of "Being" that is the real enigma. Kezilahabi uses the Swahili word kuwako, the infinitive of locative being, which means "to be present, to be here/there, to exist" or the appropriate verbal nouns from these verbs. It is "being" in a locative sense. While kuwa means "to be" (the root $-w a$ is not a cognate of the copula $n i$, but it is used as its infinitive), the $-k o$ at the end has an almost identical meaning to that of the German $d a$ - in dasein or Dasein: "to be present, to exist". Kezilahabi's sentence, msingi wake ni kuwako ("its foundation is being"), does not make much sense to a Swahili speaker unfamiliar with Heidegger: you never say ni kuwako ("it is being"); kuwako is either used as an infinitive or conjugated with a personal prefix (e.g. niko "I am (here/somewhere)").

Kuwako, therefore, is locative; "being" is transformed into "being-there", Sein into Dasein, esse into "existence". Kwasi Wiredu, when talking about the expression of "being" in Akan, says that "in Akan the concept of existence has an explicitly locative connotation" (Wiredu 1996: 121); he uses this as an argument in support of his suggestion that the existential, non-locative being of the Cartesian cogito (derived from the Scholastic concept of the being of God) would not make sense in Akan and is, perhaps, an "ontological fantasy" (Wiredu 2002: 57). On the other hand, William Mkufya uses kuwa for the being of God and of immaterial entities such as devils, as opposed to kuwako, which pertains to human and other material beings (1999: 41 and 48). So it is not the case that the distinction between "being" and "existence" is prima facie impossible in Swahili.

I argue Kezilahabi is "destructive" also to Heidegger. On the one hand, he destroys his third "eye-opener" through the act of violence, the chaotic dance of philosophers which reshuffles the philosophical cards; on the other hand, simultaneously, and perhaps more radically, he is also destructive to Heidegger through his translation of "Being" as kuwako. He reduces "Being" to a simple 
act of existing; this reading of "Being" does not even remotely match the Heideggerian meaning of "Being". The destructive approach helps Kezilahabi abandon even his philosophical sources completely and go his own way. There is one way to "salvage" kuwako - namely when it is what follows upon destruction. Kezilahabi implements this destruction both on the level of content (the destructive chaotic dance) and on the level of linguistic expression.

Kuwako is defined, on the one hand, through the locative meaning of the translated word and, on the other, through the fictional setting in which it is introduced: it is the foundation of a new epistemology, of an ontological form of life, of the overcoming of the subject-object dichotomy. It is a "rewriting", "translating and transferring" (Gaudioso 2015) of the Heideggerian concept of "Being" in the sense of emptiness, openness, bare existence. Similar to Sartre, ${ }^{7}$ Kezilahabi is suggesting that no positive fulfilment, no "authenticity" is possible but a total lack of determination, which is the grounding of radical freedom. The scenes of destruction are significant because destruction has the role of reconfiguration. Chaos prepares the ground for a new world. What remains is bare existence, emptiness as a basis for self-projection and self-creation in freedom, for construction and casting into existence. Then it also makes sense to speak of the silent language of being and the absence of the subject-object duality.

Kuwako is the overcoming of categories of Being - overcoming beings - in favour of bare existence. It is what follows upon destruction and upon the abolition of the subject-object dichotomy. Kezilahabi's understanding of Being is thus existentialist, not essentialist. It is existence which escapes determinants (such as "African" or "authentic") and must be distinguished from "African essence", for which Kezilahabi coins the word "Quassia" (1985: 237 and passim) in his thesis. From this, truth for him is not unconcealment (aletheia) but creation - this is at the basis of his "creative and projective" (Kezilahabi 1985: 195) literature. Essentialism is self-defeating if preceded by Vurumai! ("Chaos!"), because kuwako is empty. It is not a content or an authenticity: Vurumai! evacuates "Being". Despite the obvious Heideggerian resonances and assonances, Kezilahabi is taking the Heideggerian concept of "Being", which he renders in Swahili as kuwako, elsewhere.

\section{Conclusion: projective literature, redemptive writing}

Kezilahabi's project has two parts: destruction and (re)construction. The destructive phase creates a discontinuity, it leaves nothing to represent; the new world is built on the ruins of the old world, but it is not an emanation of the old. Then this

7 Kezilahabi does not reference Sartre in his thesis (1985). Among the sources of the existentialist orientation of his early prose he mentions Beckett and Camus (Bernarder 1977: 49). Any influence of Sartre on Kezilahabi would have been indirect, the main connecting link being Frantz Fanon. Kezilahabi read Fanon in Constance Farrington's translation (referenced in Kezilahabi 1985) which, according to Kathryn Batchelor (2015), "de-philosophizes" Fanon and especially distances him from Sartre (cf. also Mazrui 2017). In view of the prominent role of "violence" and "destruction" in Kezilahabi and in view of the dramatic shift in understanding "violence" on account of Farrington's translation (Batchelor 2015), the influence of Fanon on Kezilahabi would merit a more focused discussion than can be delivered in this article. 
lugha ambayo haina cha Mtu na Kitu can write the truly new, the future, the possible. And then it does not represent but is reality. Bare existence becomes the new foundation. The "language which does not contain the distinction between Man and Thing" and "whose foundation is being" is the language of a literature which abandons the mimetic link to the world. It rejects the reproduction of reality - which is the reality of a colonized/post-colonial continent - and instead projects one of freedom. This literature projects an African future ex nihilo, from the emptiness after destruction.

Kezilahabi makes his kuwako the foundation of a projective, emancipatory writing. He therefore mainly connects it to literature, and then his redemptive writing means literature which does not signify and have referents but which is, which projects and makes rather than reproduces. But literature always has an ontological meaning to Kezilahabi; it entails an existential project: the emancipation of Africa. Writing becomes emancipatory because it does not portray actuality but possibility and projects a new, "yet unimagined" future for Africa and, indeed, for the whole of humanity. The step of "destruction" is radical enough to stop writing who we are and instead aspire to write who we are not, who we possibly can be. The highly mystical language of Nagona and Mzingile and the stylistic erasure of textual and narrative coherence corresponds to this ambition. Euphrase Kezilahabi writes the future as not ensuing from the present; the possible as not contained in or derived from the actual.

Kezilahabi's work, in both the novels and the thesis, is not only critical of Western epistemology; it also constructs a non-mimetic view of literature theorizing it beyond the category of representation and giving it an ontological meaning: literature is a projection of (future/possible) reality. Kuwako remains an emptiness. It is what issues from vurumai - the chaotic dance that destroys and recreates, reconfigures being and knowledge.

\section{An ironic post scriptum}

While Kezilahabi's thesis militates for an emancipated Africa and develops the project of "creative and projective" (Kezilahabi 1985: 195) African literature, the two novels, as I mentioned earlier, are both more open-ended and intriguing. Kezilahabi ends Mzingile with a suggestion that perhaps the condition of radical freedom and bare existence is unsustainable and untenable as a foundation of life. The very last paragraph of the book reads:

Halafu, kwa bahati, nilipotazama kwa uangalifu chini ya kilima ni kama niliona mzee akitambaa polepole kwa magoti kuelekea kileleni. Juu ya mgongo wake, palikuwa na kitabu. Wanyama walikuwa wakicheka! (Kezilahabi 1991: 70).

Finally, by accident, when I looked carefully under the hill, it was as though I saw the old man crawling slowly on his knees towards the top. On his back, there was a book. The animals were laughing!

The "old man" is the god-like figure in the novels and the book he is dragging on his back can only be the single book that escaped the burning of all books 
when it one day mysteriously disappeared together with the old man. The book is Das Kapital.

The ending of Mzingile is, thus, destructive also to the idea of freedom, emptiness, and bare existence. The past is not erased and the future is predetermined. Radical freedom is a utopia and another circle of human folly is about to begin, with God and ideology resuming their position of power on top of the mountain.

\section{References}

Batchelor, Kathryn. 2015. "Fanon's Les Damnés de la terre: translation, de-philosophization and the intensification of violence", in Russell Goulbourne and Max Silverman (eds), Fanon in Contexts: Essays in memory of David Macey, special issue of Nottingham French Studies 54/1, 7-22.

Bernarder, Lars. 1977. "Ezekiel (sic!) Kezilahabi - narrator of modern Tanzania”, Lugha 1, 46-50.

Farías, Victor. 1989. Heidegger and Nazism. (Edited, with a foreword, by Joseph Margolis and Tom Rockmore. Translated by Paul Burrell, Dominic Di Bernardi, and Gabriel R. Ricci.) Philadelphia: Tempels University Press. (Originally published in 1987.)

Faye, Emmanuel. 2009. Heidegger. The Introduction of Nazism into Philosophy. (Trans. Michael B. Smith, Foreword Tom Rockmore.) New Haven and London: Yale University Press. (First edition in French 2005.)

Gaudioso, Roberto. 2014. "Kuwako na wakati: mipaka ya lugha kama hatua za falsafa katika mashairi ya Euphrase Kezilahabi”, Swahili Forum 21, 76-103.

Gaudioso, Roberto. 2015. "Transferring and rewriting freedom in Euphrase Kezilahabi", Nordic Journal of African Studies 23/2, 63-89.

Gaudioso, Roberto. Forthcoming. "Euphrase Kezilahabi's thinking poetry", in Alena Rettová, Benedetta Lanfranchi, and Miriam Pahl (eds), Asixoxe - Let's Talk! New Trends in African Philosophy (provisional title).

Gromov, Mikhail D. 2014. "Visions of the future in the 'new' Swahili novel: hope in desperation?" Tydskrif vir letterkunde 51/2, 40-51. http://www.letterkunde.up.ac.za/ argief/51_2/04\%20Gromov\%2003\%20WEB.pdf.

Heidegger, Martin. 1991. "The self-assertion of the German university", in Richard Wolin (ed.), The Heidegger Controversy. A Critical Reader. New York: Columbia University Press, 29-39.

Heidegger, Martin. 1996. Being and Time. (First published in German as Sein und Zeit, 1927.) Trans. Joan Stambaugh. Albany: State University of New York Press.

Heidegger, Martin. 1998. "Letter on 'Humanism'”. (First published in German 1946.) Trans. Frank A. Capuzzi, in William McNeil (ed.), Pathmarks. Cambridge: Cambridge University Press, 239-76.

Heidegger, Martin. 2000. Introduction to Metaphysics. Lecture from 1935. Trans. Gregory Fried and Richard Polt. New Haven and London: Yale Nota Bene (Yale University Press).

Kagame, Alexis. 1955. La philosophie bantu-rwandaise de l'Être. Brussels: Pontificia Universitas Gregoriana.

Kagame, Alexis. 1976. La philosophie Bantu comparée. Paris: Présence africaine.

Kezilahabi, Euphrase. 1985. "African philosophy and the problem of literary interpretation", unpublished $\mathrm{PhD}$ dissertation, University of Wisconsin (Madison).

Kezilahabi, Euphrase. 1990. Nagona. Dar es Salaam: Dar es Salaam University Press. 
Kezilahabi, Euphrase. 1991. Mzingile. Dar es Salaam: Dar es Salaam University Press.

Kezilahabi, Euphrase. 2008. Dhifa. Nairobi: Vide-Muwa.

Kezilahabi, Euphrase. 2017. "The real and the imaginary: propellers of knowledge in literature", lecture delivered during the BIGSAS Denkatelier 03 at the University of Bayreuth, 26 May 2017.

Khamis, Said A.M. 2005. "Signs of new features in the Swahili novel", Research in African Literatures 36/1, 91-108.

Kohák, Erazim. 1995. "Relationship between Heidegger's philosophy and Nazi ideology”, unpublished lecture, Charles University, Prague, 5 March 1995.

Lanfranchi, Benedetta. 2012. "Daring to be destructive: Euphrase Kezilahabi's ontocriticism", Swahili Forum 19, 72-87. http://www.qucosa.de/fileadmin/data/qucosa/ documents/10743/SF_19_5_Lanfranchi.pdf.

Lanfranchi, Benedetta. 2015. "Judging crimes against humanity in Acholi. A philosophical interpretation of the use of Acholi traditional justice mechanisms in the aftermath of the war in northern Uganda", unpublished PhD thesis, SOAS, University of London.

Löwith, Karl. 1991. "The political implications of Heidegger's existentialism", in Richard Wolin (ed.), The Heidegger Controversy. A Critical Reader. New York: Columbia University Press, 167-85.

Massamba, David P.B. 2004. Kamusi ya Isimu na Falsafa ya Lugha. Dar es Salaam: Chuo Kikuu cha Dar es Salaam.

Mazrui, Alamin. 2017. "Fanon in the East African experience: between English and Swahili translations", in Kathryn Batchelor and Sue-Ann Harding (eds), Translating Frantz Fanon Across Continents and Languages. New York and London: Routledge, 76-97.

Mkufya, William E. 1999. Ziraili na Zirani. Dar es Salaam: Hekima Publishers.

Ngugi wa Thiong'o. 1981. Decolonising the Mind. The Politics of Language in African Literature. London: James Currey.

Nietzsche, Friedrich (no date). Also Sprach Zarathustra. First edition 1883-85. http:/ www.zeno.org/Philosophie/M/Nietzsche,+Friedrich/Also+sprach+Zarathustra.

Nietzsche, Friedrich. 2008. Thus Spake Zarathustra. Trans. Thomas Common. http:/ www.gutenberg.org/files/1998/1998-h/1998-h.htm.

Ott, Hugo. 1993. Martin Heidegger. A Political Life. Trans. Allan Blunden. London: Harper Collins Publishers.

Rettová, Alena. 2007. “Lidství ni Utu? Ubinadamu baina ya Tamaduni”, Swahili Forum 14, 89-134. http://www.qucosa.de/fileadmin/data/qucosa/documents/9767/14_06_ Rettova.pdf.

Rettová, Alena. 2016a. "Writing in the swing? Neo-realism in post-experimental Swahili fiction", Research in African Literatures 47/3, 15-31, doi: 10.2979/ reseafrilite.47.3.02.

Rettová, Alena. 2016b. "From Mimesis to Mize. Philosophical implications of departures from literary realism", in Clarissa Vierke and Katharina Greven (eds), Dunia Yao. Utopia/Dystopia in Swahili Fiction. Cologne: Rüdiger Köppe, 113-46.

Rettová, Alena. Forthcoming. "Brave new worlds: postapocalyptic narratives in Swahili".

Safranski, Rüdiger. 1998. Martin Heidegger. Between Good and Evil. Trans. Ewald Osers. Cambridge, MA and London: Harvard University Press. Originally published in 1994.

Sartre, Jean-Paul. 1958. Being and Nothingness: An Essay on Phenomenological Ontology. First published in French as L'Être et le néant: Essai d'ontologie phénoménologique (1943). Trans. Hazel E. Barnes. London: Methuen. 
Senghor, Léopold Sédar. 1995. "On Negrohood: psychology of the African negro", trans. H. Kaal, in Albert G. Mosley (ed.), African Philosophy. Selected Readings. Englewood Cliffs, NJ: Prentice Hall, 116-27.

Tchokothe, Rémi Armand. 2014. Transgression in Swahili Narrative Fiction and Its Reception. Vienna: LIT Verlag.

TUKI. 1990. Kamusi Sanifu ya Isimu na Lugha. Dar es Salaam: Chuo Kikuu cha Dar es Salaam.

Wiredu, Kwasi. 1996. Cultural Universals and Particulars. An African Perspective. Bloomington and Indianapolis: Indiana University Press.

Wiredu, Kwasi. 2002. "Conceptual decolonization as an imperative in contemporary African philosophy: some personal reflections", Rue Descartes 36, 53-64.

Wolin Richard (ed.). 1991. The Heidegger Controversy. A Critical Reader. New York: Columbia University Press.

Zeytinoglu, Cem. 2011. "Appositional (communication) ethics: listening to Heidegger and Lévinas in chorus", Review of Communication 11/4, 272-85. 